\title{
Will Asian Women Call a Telephone Health Information Service?
}

\author{
Sharon Watkins Davis \\ Northern California Cancer Center
}

\begin{abstract}
AAPI women have the lowest breast cancer screening rates of all U.S. women. Barriers to screening include access, culture, and language. Previous focus group studies have shown little use of telephone hotlines among Asians. However, this report indicates that media promotions in Cantonese, Mandarin, Vietnamese, and Korean can result in a major increase in calls to a California statewide telephone service. Calls from women speaking Asian languages to the California Breast Cancer Early Detection Program Consumer 800 Number increased from an average of 24 per month to 576 in June 2001 in response to paid newspaper and radio advertisements in Los Angeles, San Diego, and the San Francisco Bay Area.
\end{abstract}

(C) 2003 Californian Journal of Health Promotion. All rights reserved.

Keywords: Asian women, cancer, primary prevention, early detection

\section{Background and Significance}

Breast cancer incidence and mortality rates are lower for Asian American and Pacific Islander (AAPI) women than for Whites or Blacks in the United States (American Cancer Society, 2001). However, invasive breast cancer rates increased by about 15 percent among AAPI women in California from 1998 - 1997, compared with fairly stable rates for other ethnic groups (American Cancer Society, California, 2001). Cancer rates also differ among AAPI subgroups; breast cancer is the leading cause of cancer death among Filipino and Korean females in the United States (Chu, 1998).

Breast cancer screening with mammograms reduces the number of deaths from breast cancer for women age 40 to 69 (National Cancer Institute, 2000). However, AAPI women have the lowest breast cancer screening rates for all U.S. women (Kagawa-Singer, 1996). There are many barriers to cancer screening among AAPI women, including limited education, recent immigration, limited English proficiency, Eastern medicine orientation, limited access to health care, and social isolation (McPhee, 1998). Health education outreach programs have encountered formidable barriers when trying to connect with Asian audiences (Sadler, 1998). Having a physician recommend breast screening was found to be crucial in order to overcome a cultural belief that if nothing is wrong, no tests should be done. Cost and insurance barriers were also shown to be major concerns (Lee, 1998).

AAPI women seek health information from health professionals, including traditional medicine practitioners such as herbalists, family members, and the media. However, health information sources for Asians cited in a focus group study did not include hotlines (Deering, 1996). AAPIs represent only $1.7 \%$ of callers to the National Cancer Institute's Cancer Information Service (1-800-4-CANCER)(Ward et al., 1998). We were unable to identify any statewide hotlines offering breast cancer information in Asian languages other than the one described below.

\section{California Breast Cancer Early Detection Program}

The California Department of Health Services (CDHS) established the Breast Cancer Early Detection Program (BCEDP) statewide 800 number in the fall of 1995 to provide access to free clinical breast exams and mammograms for low-income women who do not have health insurance. Telephone Information Specialists: 1) screen each woman for age, income, and insurance eligibility for the program; 2) complete an application form for eligible 
women; 3) identify up to three clinical breast exam providers located near each woman; 4) mail the application form and printed referral list, cover letter and brochure to the woman; and 5) make follow-up calls to eligible women.

Two recent innovations in BCEDP were implemented to reach monolingual Asian women. First, the telephone system was expanded late September 2000 to handle calls in
Cantonese, Mandarin, Vietnamese, and Korean. Second, a series of language-specific paid print and radio promotions was targeted to three major California Asian media markets in May and June 2001 (Table 1). In addition to the placements listed in the table, advertisements were inserted into five statewide magazines. Approximately $\$ 50,000$ was spent to purchase the media placements (Figures 1-3).

Table 1

Asian media paid advertisements promoting BCEDP targeted to Los Angeles, San Diego, and the San Francisco/Bay Area, May 29 - June 24, 2001

\begin{tabular}{|c|c|c|c|}
\hline & San Francisco/Bay Area & Los Angeles/Orange County & San Diego \\
\hline Newspaper & $\begin{array}{l}\text { Sing Tao Daily News } \\
\text { World Journal } \\
\text { Korea Central Daily } \\
\text { Korea Times } \\
\text { Vietnam Daily News } \\
\text { Viet Mercury }\end{array}$ & $\begin{array}{l}\text { Sing Tao Daily News } \\
\text { World Journal } \\
\text { Daily Sports Seoul USA } \\
\text { Korea Central Daily } \\
\text { Korea Times } \\
\text { Little Saigon News } \\
\text { Nguoi Viet Daily News } \\
\text { Saigon Times }\end{array}$ & $\begin{array}{l}\text { Chinese News } \\
\text { American Chinese Times } \\
\text { Korea Central Daily } \\
\text { Korea Times } \\
\text { Nguoi Viet Daily News } \\
\text { Saigon Times }\end{array}$ \\
\hline Radio & $\begin{array}{l}\text { KVVN (Mandarin) } \\
\text { KEST (Cantonese) } \\
\text { KVTO (Korean) } \\
\text { KSJX (Vietnamese) } \\
\end{array}$ & $\begin{array}{l}\text { KAZN (Mandarin) } \\
\text { KMRB (Cantonese) } \\
\text { KYPA (Korean) } \\
\text { KVNR (Vietnamese) } \\
\end{array}$ & $\begin{array}{l}\text { Radio Seoul (Korean) } \\
\text { KSON (Vietnamese) }\end{array}$ \\
\hline $\begin{array}{l}\text { Telephone } \\
\text { Directories }\end{array}$ & $\begin{array}{l}\text { Chinese Yellow Pages } \\
\text { The Korea Times Directory } \\
\text { Vietnamese Directory USA }\end{array}$ & $\begin{array}{l}\text { Chinese Yellow Pages } \\
\text { Korean Yellow Pages } \\
\text { Vietnamese Consumers' Guide }\end{array}$ & $\begin{array}{l}\text { Chinese Yellow Pages } \\
\text { The Korea Times Directory } \\
\text { Vietnamese Chamber of } \\
\text { Commerce }\end{array}$ \\
\hline
\end{tabular}

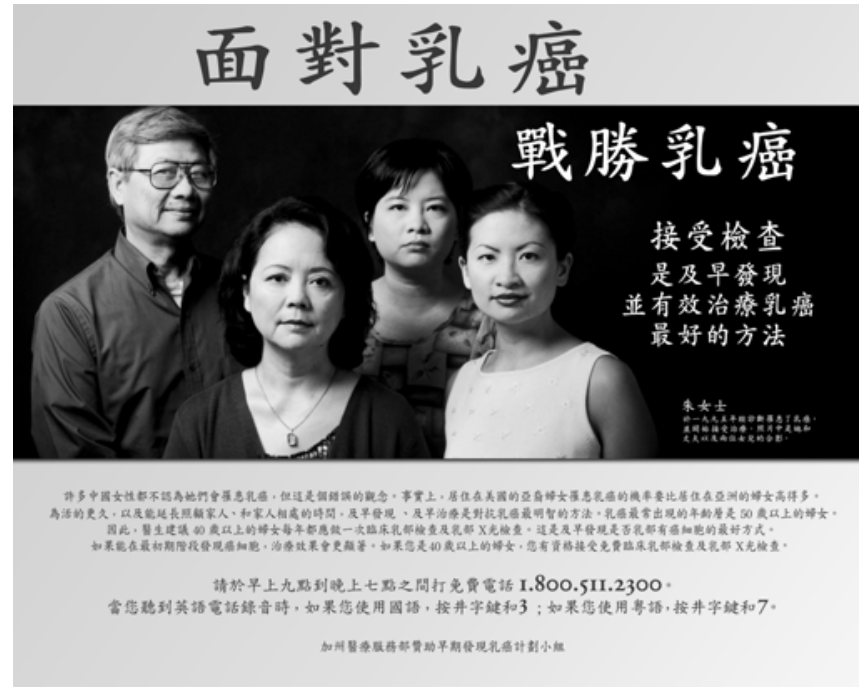

Figure 1

Breast Cancer Early Detection Program (BCEDP) Poster in Chinese 

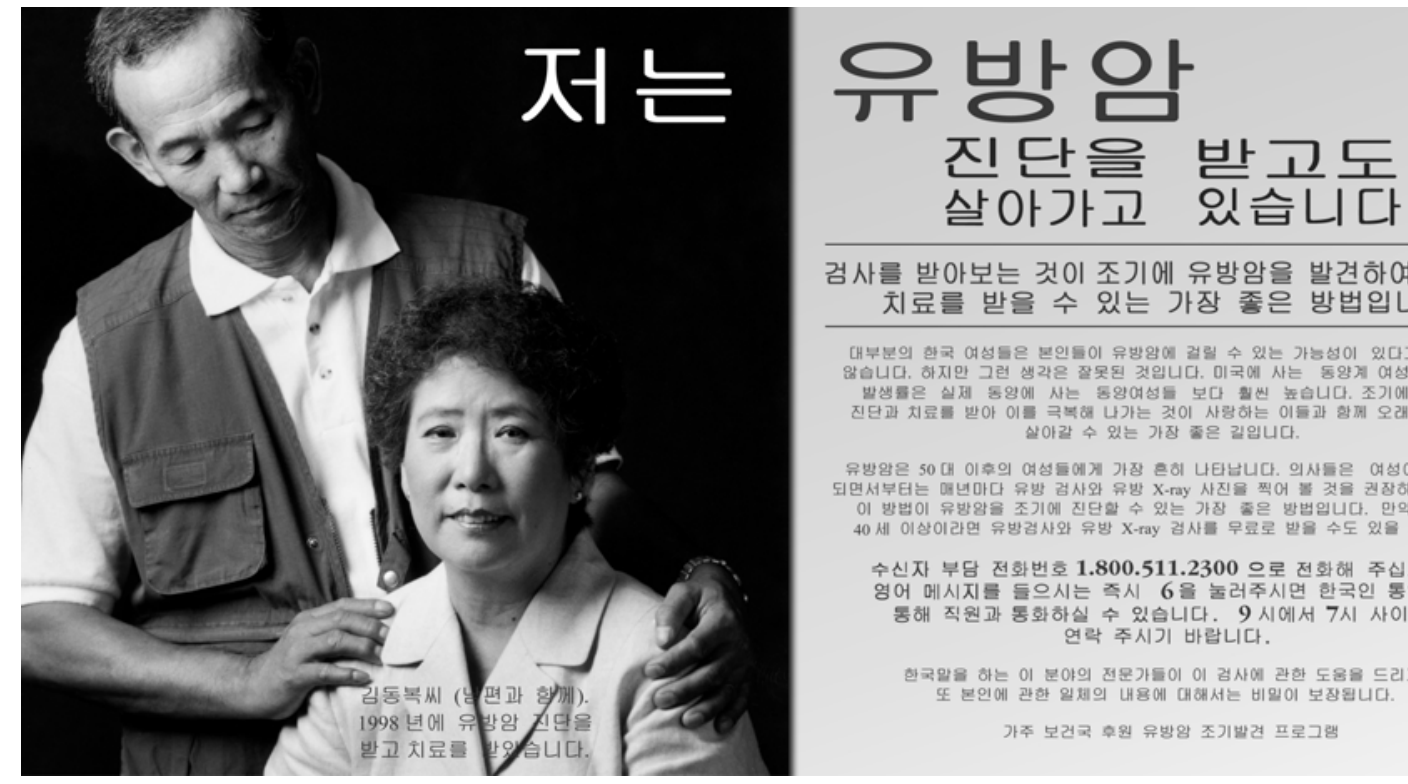

검사를 받아보는 것이 조기에 유방암을 발견하여 적절한 치료를 받을 수 있는 가장 좋은 방법입니다.

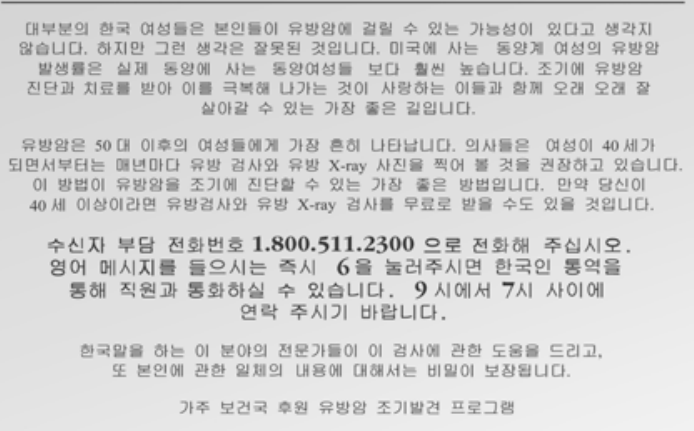

Figure 2

Breast Cancer Early Detection Program (BCEDP) Poster in Korean
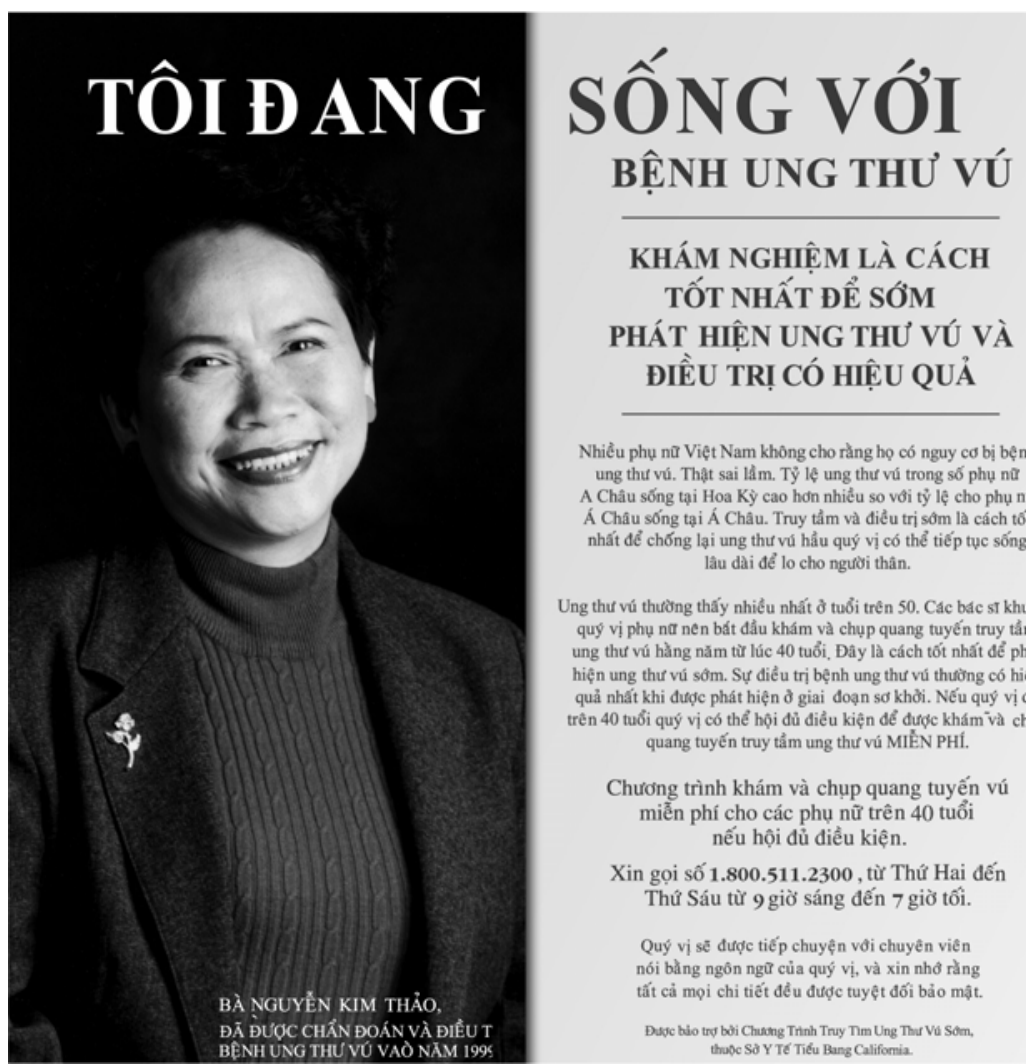

Nhiều phụ nữ Việt Nam không cho rà̀ng họ có nguy cơ bị bệnh ung thư vú. Thật sai lầm. Tỷ lẹ ung thư vú trong só phụ nữ A Châu sống tại Hoa Ky cao hơn nhiéu so với tỳ lẹ cho phụ nữ

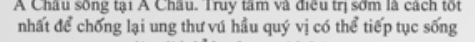
lâu dăi đé̉ lo cho ngươi thân.

Ung thư vứ thường thấy nhiêu nhất ờ tuới trên 50 . Căc bảc st khuyen qự vị phụ nư nen bát đầu khám và chụp quang tuyến truy tẩm ung thư vứ hà̀ng năm từ lúc 40 tuới, Dây là cách tốt nhắt để phát hiện ung thư vú sợm. Sự điểu trị bệnh ung thư vú thường có hiệu quả nhất khi được phát hiện ò giai đoạn sơ khời. Nếu quy vị đã trền 40 tuối quý vị có thể hội đủ điểu kiện đé được khám và chụp quang tuyến truy tả̉m ung thư vú MIẾN PHI.

Chương trình khám và chụp quang tuyến vứ miễn phí cho các phụ nữ trên 40 tuổi nếu hội đủ điểu kiện.

Xin gọi số 1.800.511.2300, từ Thứ Hai đến Thứ Sáu từ 9 giờ sáng đến 7 giờ tối.

Quý vị sẽ được tiếp chuyện vợi chuyên viên nói bằng ngôn ngư của quý vị, và xin nhở rằng tất cả mọi chi tiết đểu được tuyệt đối bảo mật. Desce bido tro bot Chushig Tinht Truy nm Ung Thu Vu Som,

Figure 3

Breast Cancer Early Detection Program (BCEDP) Poster in Vietnamese 
The advertisements said, "I am living with breast cancer. An exam is the best way to find breast cancer early enough to treat it effectively. Many (Chinese, Vietnamese, Korean) women do not think that they are at risk for getting breast cancer. They are wrong. Breast cancer rates for Asian women living in the United States are much higher than they are for Asian women living in Asia. Finding and treating breast cancer early is the best way to fight the disease so that you can live a long time to take care of those you love. Breast cancer occurs most often in women over age 50. Doctors recommend a clinical breast examination and mammogram every year for women beginning at age 40 . This is the best way to find breast cancer early. Treatments for breast cancer are most effective when the cancer is found in its earliest stages. If you are over age 40 you may qualify for a FREE clinical breast examination and mammogram. Please call 1-800-511-2300. You will be able to speak with a trained professional and your information will be kept strictly confidential. Sponsored by the California Department of Health Services, Breast Cancer Early Detection Program." The advertisement was translated into each language. A compelling photograph of an actual breast cancer survivor of the appropriate ethnic group with one or more family members appeared to the left of the text. Not only did this put a relevant "face" to the issue for readers and listeners, it also resulted in over 20 broadcast and eight print interviews with the survivors across the state.

\section{Results}

The number of Asian calls increased dramatically in May and June, as shown in Figure 4, and began to converge on the number of Spanish calls. Asian calls increased from an average of 24 per month during October through April to 119 in May and 576 in June. Over the nine months from October through June, the BCEDP Consumer 800 Number handled 270 calls in Mandarin, 153 in Cantonese, 175 in Vietnamese, and 263 in Korean. These results indicate that media promotions in Cantonese, Mandarin, Vietnamese, and Korean can generate a major increase in calls to a California statewide telephone service.

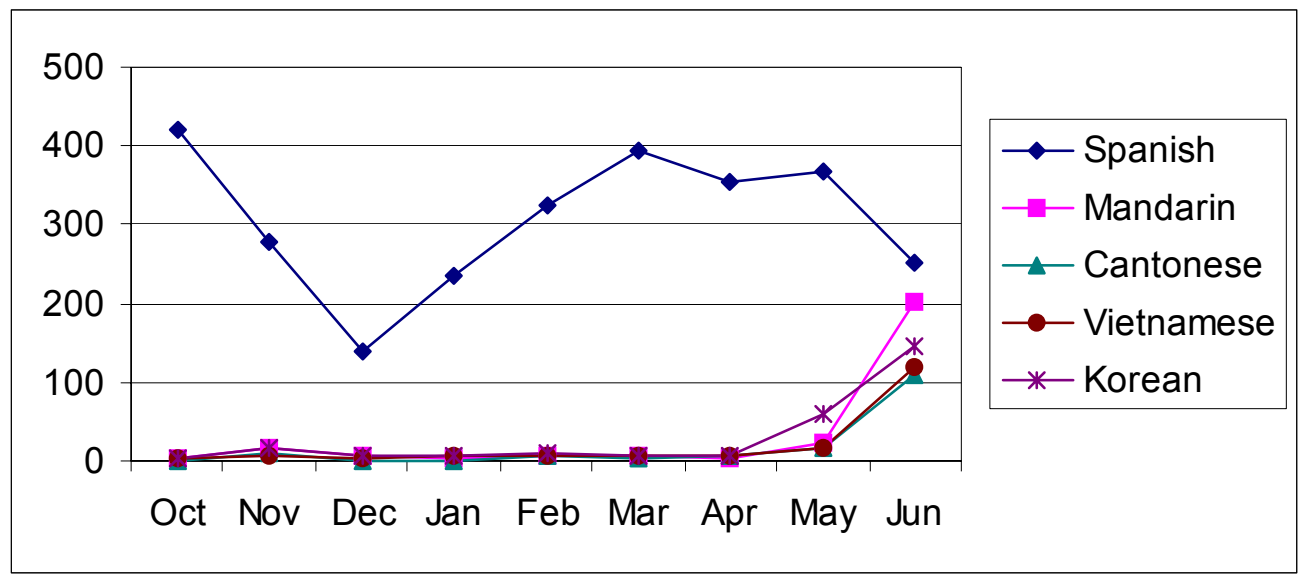

Figure 1

Number of non-English calls to the California Breast Cancer Early Detection Program Consumer 800 Number, October - June 2001 


\section{Discussion and Implications for Health Education}

Monolingual, non-English speaking communities have been challenging for health educators to reach (Sadler, 1998). Successful interventions have traditionally involved intensive, community-based education with native speakers (McPhee, 1998). Health educators have not made much use of telephone help lines for this audience, possibly due to the belief that they would be ineffective.

This study demonstrates that targeted advertising, using role models, is successful in reaching Chinese, Vietnamese, and Korean audiences. AAPI women were willing to call an anonymous 800 number and engage in a threeway translated call.

There is a major limitation in considering this study's application to general health promotion. In this study, women were calling to receive a free service worth at least $\$ 100$ (clinical breast exam and mammogram). This may have been considerably more motivating than an appeal for something less tangible, such as health information. Another limitation is the lack of information about which of the women who called the service actually followed through and obtained the mammogram, and which maintained routine screening.

In spite of these limitations, the success of these promotional efforts should encourage health educators to consider targeted radio and newspaper advertisements in native languages. Using real members of the community provided additional credibility and enabled us to obtain additional media coverage through news and talk radio interviews. In addition, telephone help services may be useful in other efforts that require detailed information and referral for monolingual populations. Further research could be done on the cost-effectiveness of intensive community outreach compared with media promotions for a telephone help service.

\section{References}

American Cancer Society. (2001). Cancer facts and figures 2001. Atlanta, GA: American Cancer Society. American Cancer Society, California. (2001). California cancer facts and figures 2001. Oakland, CA: American Cancer Society, California Division.

Chu, K. C. (1998). Cancer data for Asian Americans and Pacific Islanders. Asian American and Pacific Islander Journal of Health, 6, 130-139.

Deering, M. J. (1996). Consumer health information demand and delivery: Implications for libraries. Bulletin of the Medical Library Association, 84, 209-216.

Kagawa-Singer, M. (1996). Issues affecting Asian American and Pacific American women. In HasseyDow (Ed.), Contemporary issues in breast cancer. Boston: Jones and Bartlett.

Lee, M. (1998). Breast and cervical cancer early detection in Chinese American women. Asian American and Pacific Islander Journal of Health, 6, 351-357.

McPhee, S. J. (1998). Promoting breast and cervical cancer screening among Vietnamese American women: Two interventions. Asian American and Pacific Islander Journal of Health, 6, 344-350.

National Cancer Institute (2000). Questions and answers about screening mammograms. Cancer Facts, 5, 28.

Sadler, G. R., Nguyen, F., Doan, Q., Au, H., and Thomas, A. G. (1998). Strategies for reaching Asian Americans with health information. American Journal of Preventive Medicine, 14, 224-228.

Ward, J. A. D. Baum, S., Ter Maat, J., Thomsen, C. A., and Maibach, E. W. (1998). The value and impact of the cancer information service telephone service. Part 4. Journal of Health Communications, 3 (Suppl.), 50-70. 


\section{Acknowledgments}

This study was supported by the California Department of Health Services, Cancer Detection Section, Contract 00-90632, "Breast Cancer Early Detection Program (BCEDP)."

I am grateful to Valerie Quinn, M.Ed., Health Program Specialist at the Cancer Detection Section, for reviewing the manuscript, and to Robert Berger, President, Healthier Solutions, for providing data on media placements, and granting permission to reprint the posters for this article. Special thanks to the Cancer Detection Section's Asian Pacific Islander Task Force for the vision for recommending the telephone services be expanded to include Cantonese, Mandarin, Vietnamese and Korean.

Author Information

Sharon Davis, MPA

Northern California Cancer Center

32960 Alvarado-Niles Road

Union City, CA 94587

E-Mail: sdavis@nccc.org 